\title{
Tax planning in Australia's income tax system
}

\author{
Tristram Sainsbury and Robert Breunig ${ }^{1}$
}

\section{Abstract}

Has income tax become voluntary in Australia? It appears that for some, nil or very low tax bills are a real prospect. Those with flexibility over how income is earned and motivation to achieve tax savings can structure their financial affairs to channel income through a mix of companies, trusts, assets, superannuation and family members over time. This article presents some of the simpler strategies available within the Australian tax system and shows how these are available to people across the income distribution. However, a tax system designed to encourage tax planning runs counter to core principles of good tax design of fairness, efficiency and simplicity. It also raises questions about the sustainability of Australia's tax system. Addressing the structural incentives to engage in tax planning requires a wholesale rethink about the design and role of income in Australia's tax system.

\section{Introduction}

Australia relies heavily on the direct taxation of income to raise government revenue. According to the 2019-20 Mid-Year Economic and Fiscal Outlook, the federal government expected to raise 17 per cent of Australiass GDP from individual and company taxes in 2019-20 (Frydenberg \& Cormann, 2019b). A point made in major Australian tax reviews, as well as in publications from international institutions such

1 The Australian National University, robert.breunig@anu.edu.au. The authors thank Josh Pooley, David Hansell, Andrew Carter, Shawn Quinton, Paul Beohm, Graeme Davis, Greg Derlacz, Shelby Schofield, Nitin Srivistava, Kristen Sobeck, William Coleman and two anonymous reviewers for helpful comments. 
as the International Monetary Fund and the Organisation for Economic Cooperation and Development (OECD), is that Australia's strong reliance on income taxes for revenue-raising makes us an outlier among the international community. Based on the latest available internationally comparable data (excluding social security taxes), in 2017 Australia raised around 59 per cent of total tax revenue from taxes on income and profits (OECD, 2019b). The corresponding average among OECD countries was 33.2 per cent (OECD, 2019a).

At the same time, Australia's income tax system design features a range of tax planning and arbitrage opportunities. The opportunities are a result of two 'structural' features of the income tax system: different tax rates apply to different tax vehicles, and some taxpayers can defer their tax liabilities to a later point in time. People looking for flexibility or control over their income streams have the choice of a range of trusts, companies, partnerships and self-managed superannuation funds. Combined effectively, tax structuring allows some Australians to achieve highly 'tax effective' outcomes, with the most ambitious arrangements carrying the prospect of no tax liability at all.

It is important to recognise that a common feature of such arrangements is their permissibility under Australian law. Further, tax considerations are just one of many reasons people might make use of a superannuation fund, partnership, trust or company. That said, the potential availability of different tax outcomes for the same underlying economic activity represents a form of tax base erosion from Australia's personal income tax. The widespread use of such opportunities can therefore be considered the domestic Australian version of tax base erosion and profit shifting (also known as BEPS), the well-discussed corporate strategy for reducing corporate tax owed.

It is impossible, looking at the data, to determine how much tax planning is simple for purposes of tax avoidance with no other objective. If it were, the Australian Taxation Office (ATO) could prevent taxpayers from engaging in the behaviour under general compliance rules. What is clear is that the amount of activity of the type that we discuss below is increasing rapidly over time, even as other economic activity is not increasing as quickly. This at least hints at the possibility that use of tax minimisation schemes are more about tax avoidance and less about legitimate economic activity.

In this article, we present an explanation of some of the simpler tax approaches and structures that are available within the Australian taxation system. Even these simple approaches reveal that tax planning can deliver more tax effective outcomes to a wide range of Australians.

We present the examples with three specific goals in mind. 
First, their existence makes for a compelling argument to reform Australia's hybrid income tax system. Low tax rates applying to particular asset classes (housing and superannuation) prompt an overinvestment in these asset classes, while tax rates on personal incomes are higher than they could be. The myriad of options available to taxpayers requires a complex tax code. It is becoming increasingly unlikely that people in similar positions are paying similar amounts of tax. It is also impossible to determine if people who have a greater capacity to pay tax actually pay more tax.

What would be ideal is a level-headed public debate about the relative merits of moving towards a tax system with less incentive to arbitrage-reducing the gap between tax rates on personal, business and savings income-or perhaps accepting the complications that come from a number of different definitions of income, and pursuing reforms that place robust boundaries around them. Such a discussion would need to take place in the wider context of the tax and transfer system in order to maintain the desired level of progressivity of the overall system.

Second, they reveal that the current empirical evidence base around tax planning is sadly lacking. Current distributional analysis of tax burdens generally compares people's taxes in any given (annual) snapshot, which can provide a fundamentally misleading picture about someone's true over-time tax burden. The only solution to this dilemma is to build the evidence base by investing in our collective capacity to undertake genuine lifetime distributional analysis.

Third, we want to make an appeal to society to acknowledge that income tax should not be voluntary or temporary in nature. And for that to happen, Australian society needs to buy in to the notion that we collectively can't afford for specific groups of people to be treated as special in the eyes of the tax system.

We conclude by highlighting how restoring a sense of fairness into the Australian tax system is a significant task that will take coordinated policymaking action.

\section{The elements of tax planning}

\section{Important definitions for tax planning in Australia's hybrid income tax system}

In this article we make frequent use of four terms, which we define as follows.

A tax vehicle refers to any of a variety of the types of taxpaying entities that the ATO recognises. The most popular tax vehicles are an individual, a trust, a partnership, a company and a superannuation (super) fund. 
A tax structure makes use of a combination of tax vehicles in order to legally achieve a different tax outcome than would be realised through a single tax vehicle.

Tax arbitrage refers to actions that make use of available tax vehicles and structures to achieve a tax reduction through a lower tax rate. It can be thought of as a specific form of arbitrage; the general concept that concerns the simultaneous buying and selling of an asset (or store of value) in order to take advantage of different prices for the same asset. Tax arbitrage relies on different varieties of tax vehicle paying different tax rates on a marginal dollar of income.

Tax planning refers to strategies that combine vehicles, structures and arbitrage to keep tax to a minimum (ATO, 2020). Taxpayers that control how they receive income have two primary incentives to plan. Shifting income from a high-taxing to low-taxing structure delivers an immediate tax saving. Deferring a nominal tax liability into the future increases the tax saving as long as the interest rate on income is positive. The tax saving is even larger if deferral means the income attracts a lower tax rate in the future than it does in the present.

Based on the broadly accepted Schanz-Haig-Simons ${ }^{2}$ definition of income, Australia's income tax system is a 'hybrid' between the two 'pure' tax approaches that governments can adopt (of 'comprehensive' or 'schedular' taxation ${ }^{3}$ ). Australia's particular interpretation sees most forms of personal income (wages, salaries, interest, dividends and rent) taxed under a global regime at full progressive rates. Corporate income and some capital gains are taxed under the same global regime, but at flat rates. Some capital income receives discounted tax treatment under the global regime, while other capital income (linked to retirement savings) is taxed under its own schedule. ${ }^{4}$

The resulting spectrum of marginal tax rates, as at the 2019-20 financial year, is shown in Figure 1.

\footnotetext{
2 The comprehensive measure of income advocated for by Schanz (1896) and developed by Haig (1921) and Simons (1938) is generally considered by economists to be the best measure of wellbeing. That said, income tax benchmarks typically depart from a 'pure' Schanz-Haig-Simons definition in important places. It is common, for example, to evaluate tax expenditures by defining a progressive personal income tax schedule on a nominal, realisation basis as the structural 'base' feature of the Australian tax system (e.g. Commonwealth of Australia, 2020). 3 A comprehensive global income tax sees all income aggregated and taxed under a single rate schedule. In contrast, a schedular system sees different income types taxed under different schedules. For example, a schedular dual-income tax system would see labour income taxed at progressive personal rates and capital income taxed at a flat rate.

4 The particular interpretation of income within the Australian tax system (which can be described as a comprehensive income tax base with schedular pockets) means there is no neat distinction between 'labour' and 'capital' income. For example, personal income taxation incorporates wage and salary incomes, but also dividends, interest, rent and discounted capital gains. And while it captures some forms of capital gains, it won't capture all capital. Caution is therefore required when interpreting what income taxes imply about the level of taxation on labour and capital sources of income.
} 


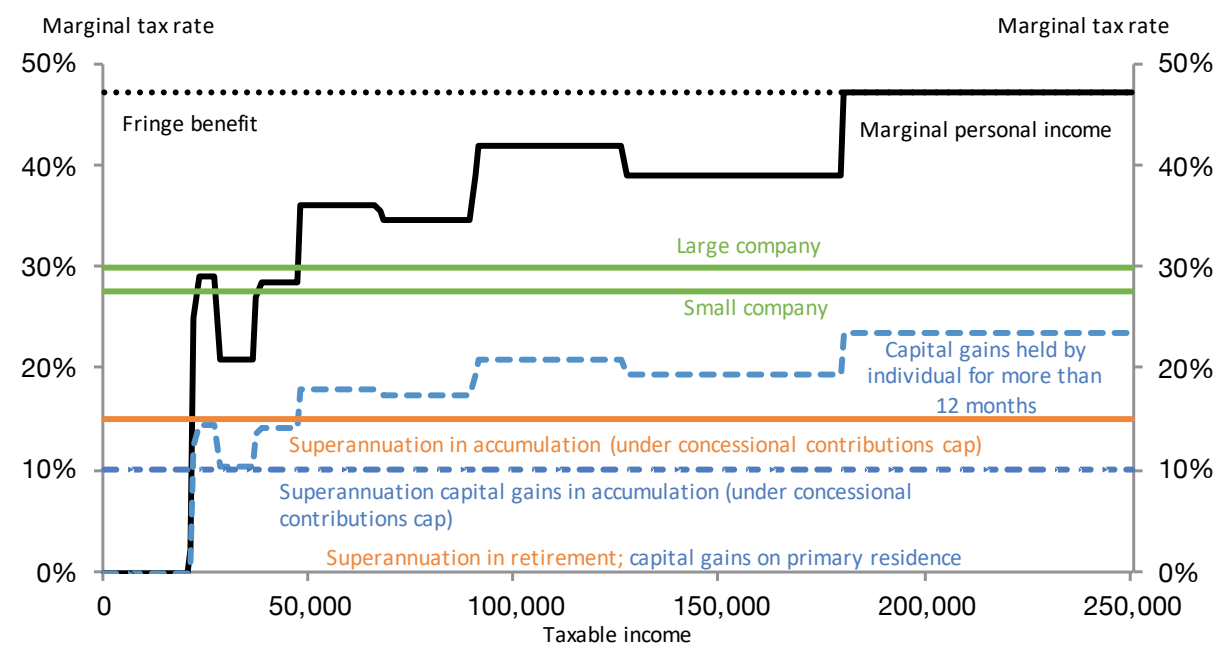

Figure 1. Marginal income tax rates for first $\$ 200,000$ of income in 2019-20

Notes: Marginal personal income tax rates include the Medicare levy, the low-income tax offset and the low- and middle-income tax offset. The large company tax rate only takes effect once a company turns over $\$ 50$ million or more. Capital gains tax is represented as a dashed line, reflecting that it is a derived calculation of an implied tax rate that applies to a discounted nominal gain during the year in which an asset is sold. However, in practice, the capital gains tax discount is applied to the gains, which are either halved (capital gains on ordinary income) or discounted by 33 per cent (capital gains on super in the accumulation phase) for assets that are sold and have been held for 12 months or longer. Then full marginal rates apply to that gain.

Source: Australian Taxation Office.

Before turning towards the interpretation of this hybrid system, it is important to remember that tax planning is entirely permissible under Australian law. ${ }^{5}$ It is a common feature of most tax systems around the world. People have every right to arrange their financial affairs effectively. Tax is a material consideration for people's financial affairs. Tax professionals are expected to provide advice that reduces people's tax liabilities, within the bounds of existing laws.

\section{Different ways to interpret the current design of the hybrid Australian income tax system}

Figure 1 shows that Australia's income tax system is complex. In 2019-20, Australian taxpayers face marginal income tax rates that range from 0 to 47 per cent. The precise rate depends on how much income the taxpayer receives, and whether its designation is as personal income, corporate income, super, capital gain or fringe benefit. For example, someone's 100,001th dollar in 2019-20 attracts a marginal tax rate of: 47 per cent if a taxable fringe benefit; 39 per cent if taxable personal income; 27.5 per cent if earned by a small business; 19.5 per cent if an individual realised

5 Lawful tax planning should be distinguished from tax evasion actions such as deliberately underreporting income or sham contracting, where people try to exploit tax and super systems in ways that are not lawful. 
a capital gain on an asset they held for more than 12 months; 15 per cent if it was the ordinary income of a super fund outside the retirement phase, and 0 per cent if the income was a capital gain earned on the primary residence, or income of a super fund during the retirement phase.

Little wonder the majority of Australian taxpayers - 71 per cent in the 2016-17 income year (ATO, 2019b) — choose to turn to a tax agent to process their tax affairs rather than engage directly with the complexity themselves.

Putting the in-your-face complexity to one side, what to make of the tax rates depends on the perspective of the viewer. For example, one perspective-which we call the policymaker's perspective - is that each separate tax rate is a design feature of the tax system. Each tax rate has been individually justified on particular economic and/or social grounds. One example is choosing to tax capital at a lower rate than 'ordinary' personal income. Another is to make small businesses subject to the lower tax rate than large businesses. Yet another is creating a tax-free threshold for the first $\$ 18,200$ of income individuals earn each year. A further example is exempting from tax all of the income earned as capital gains (or losses) on the main residence. A final example is exempting earning through super through the retirement phase, to encourage Australians to purse this particular form of saving.

Before we do that, it's worth considering another perspective-which we call the tax planner's perspective - which approaches tax as a 'minimisation' problem. For the aspiring tax planner, Figure 1 reveals that some forms of income result in lower annual tax bills than others. The tax planner's challenge is to divide their total income ${ }^{6}$ among available tax schedules in a way that gets them to the lowest total tax bill. By doing so, the tax planner also pays the lowest average rate of tax for that year across all income sources. They can then turn their attention to thinking beyond themselves (by minimising the taxes paid by their household) and to thinking beyond a single income year.

\section{Basic tax planning}

How can people take advantage of these opportunities? Below we cover some of the main 'channels of arbitrage'. Specifically, we provide three illustrative cameo-style examples of the types of financial arrangements that are of interest to the vast majority of Australian adults at some point in their lives. The cameos combine the use of pre-tax wages, property assets, trusts and companies. The arrangements

\footnotetext{
6 People will generally be less flexible about the tax rate they pay on income that they need to meet current consumption needs and more flexible in finding a tax-effective outcome on their discretionary income/savings. Tax planning decisions are based on achieving a tax-effective rate on total income, across both current and future consumption choices. We caution against limiting consideration only to the taxation of someone's savings decisions, or even more restrictively to just their investment choices.
} 
featured range from the simple and widespread to 'active' structures that stream and defer income across multiple tax vehicles over time. Such arrangements are well understood within the tax advice industry, and the advice behind them is pretty easy to access. We do not deal with the types of bespoke 'best of breed' tax arrangements that aggressively combine income splitting and tax deferral in sophisticated ways.

\section{Common and widespread: Salary packaging and the primary residence}

Something many Australians are aware of is that it is possible to reduce taxable income via salary sacrifice. Also known as salary packaging, salary sacrifice allows workers, through an arrangement with their employer, to use pre-tax salary to purchase certain goods or services (through a third party) that they would normally use after-tax income to pay for. For many Australian households, this means that they can purchase items that are important to their lifestyle, in a way that lowers tax. The potential tax savings increase with greater marginal personal tax rates.

The precise opportunities an employee can access depend on what their employer provides. ${ }^{7}$ It can include cars and associated running costs, financial loans, health insurance, childcare, electronic devices such as laptops and phones, and contributions to super. On these types of purchases, Example 1 illustrates how salary sacrifice can deliver a sizeable annual tax benefit. Note that the overall benefit an individual will receive is influenced by the terms and fees that the lease company or employer might impose in return for the opportunity.

\section{Example 1. Salary packaging}

Three single individuals, Bruce, David and Andrea, all work full-time for a company that offers a range of salary sacrificing options. All earn a salary of $\$ 100,000$ in 2019-20, and receive a 15.4 per cent compulsory contribution into their super funds from their employer. They all plan to take out a loan for a new car, spend $\$ 52,000$ after tax to maintain their lifestyle, and save the rest.

Bruce likes a simple life. He doesn't understand how salary sacrifice arrangements work and isn't interested in finding out. He resents compulsory super and is happy outsourcing his (very simple) tax return to an agent. He maintains his lifestyle (including car) using after-tax money. Bruce's tax agent tells him that his total tax bill on $\$ 100,000$ taxable income and $\$ 15,400$ compulsory super is $\$ 26,801$ at an average tax rate of 23.2 per cent.

\footnotetext{
$7 \quad$ Employers decide to allow salary packaging (and the form of that packaging, including the salary sacrificed covering the associated fringe benefits tax payable by the employer) for a range of commercial reasons, taking into account the fringe benefits tax rules and tax payments involved. Large organisations are more likely to provide access to salary sacrifice arrangements than small businesses.
} 
David has been thinking about his retirement. After a little research, he decides to salary sacrifice into super. He negotiates with his agency to continue to pay super on his $\$ 100,000$ salary while he salary sacrifices $\$ 9,600$. This brings his total super contribution to $\$ 25,000$. Otherwise, David funds the same after-tax lifestyle as Bruce. David's total income tax bill on $\$ 90,400$ taxable income and $\$ 25,000$ total super is $\$ 24,695$ at an average tax rate of 21.4 per cent. By taking advantage of one salary sacrifice opportunity, David pays $\$ 2,112$ less in income tax than Bruce.

Andrea is highly motivated to lower her tax bill. Like David, she salary sacrifices $\$ 9,600$ into super. Andrea also takes advantage of a novated lease arrangement ${ }^{8}$ in which a third-party financer buys the car and leases it to Andrea. Andrea funds a lifestyle equivalent to David and Bruce. Andrea's total income tax bill on $\$ 84,679$ taxable income and $\$ 25,000$ total super is $\$ 22,818$ at an effective tax rate of 20.8 per cent. By taking advantage of two salary sacrifice opportunities, Andrea pays $\$ 3,989$ less in income tax (personal and superannuation) than Bruce.

Table 1.1 Individual salary packaging examples

\begin{tabular}{|l|l|l|l|}
\hline & Bruce & David & Andrea \\
\hline Pre-tax wage income & $\$ 100,000$ & $\$ 100,000$ & $\$ 100,000$ \\
\hline $\begin{array}{l}\text { Concessional contribution } \\
\text { to super }\end{array}$ & $\$ 15,400$ compulsory & $\begin{array}{l}\$ 25,000(\$ 15,400 \\
\text { compulsory }+\$ 9,600 \\
\text { salary sacrifice })\end{array}$ & $\begin{array}{l}\$ 25,000(\$ 15,400 \\
\text { compulsory }+\$ 9,600 \\
\text { salary sacrifice })\end{array}$ \\
\hline $\begin{array}{l}\text { Tax on super contributions } \\
\text { (paid by fund) }\end{array}$ & $\$ 2,310$ & $\begin{array}{l}\$ 3,750(\$ 2,310 \\
\text { compulsory }+\$ 1,440 \\
\text { salary sacrifice })\end{array}$ & $\begin{array}{l}\$ 3,750(\$ 2,310 \\
\text { compulsory }+\$ 1,440 \\
\text { salary sacrifice })\end{array}$ \\
\hline $\begin{array}{l}\text { Salary sacrifice into novated } \\
\text { lease for car }\end{array}$ & $\$ 0$ & $\$ 0$ & $\$ 5,721$ \\
\hline Taxable income & $\$ 100,000$ & $\$ 90,400$ & $\$ 84,679$ \\
\hline Personal income tax & $\$ 24,497$ & $\$ 20,945$ & $\$ 19,068$ \\
\hline After-tax car contribution & $\$ 11,721$ & $\$ 11,721$ & $\$ 6,000$ \\
\hline
\end{tabular}

Notes: This is a basic scenario for illustrative purposes. Calculations are stylised. Unless otherwise specified, figures are based on headline personal, corporate and/or super tax rates and thresholds only without offsets, deductions or levies such as the Medicare levy or low-income tax offset. We've assumed that financing terms available to Bruce, David and Andrea are the same. We also haven't included 'bells and whistles' that would increase the attractiveness of salary packaging. For example: packaging the maintenance of the car (such as fuel, service costs) into the arrangement; the lease company claiming the GST and employee purchasing the car ex-GST; or the employee selling the leased car at a profit in the future. We also acknowledge that tax is only one consideration when contemplating salary sacrifice arrangements. For example, a leasing arrangement might reduce a worker's ability to swap employers. Similarly, super savings are 'locked in' relative to savings outside super.

8 Novated leasing is a three-way arrangement between a salaried employee, an employer and a finance company. The employee is responsible for the payments. The financier buys the vehicle and leases it to the employee. The employer agrees to take the payments from the employee's salary (as a 'salary sacrifice') before income tax is paid. Often the employer will do this in return for a fee that takes at least a part of the gains, and potentially a significant share of them. 
A comparison of what the different approaches adopted by Bruce, David and Andrea imply for their personal income, consumption, savings and tax rate is included below.

Table 1.2 Individual personal income, consumption and tax rate examples

\begin{tabular}{|l|c|c|c|c|c|c|}
\hline \multirow{2}{*}{ Name } & \multicolumn{2}{|c|}{ Personal income } & \multirow{2}{*}{ Consumption } & After-tax savings & \multirow{2}{*}{$\begin{array}{c}\text { Average } \\
\text { tax rate }\end{array}$} \\
\cline { 2 - 3 } & Salary & $\begin{array}{c}\text { Taxable } \\
\text { income }\end{array}$ & & In super & Total & \\
\hline Bruce & $\$ 100,000$ & $\$ 100,000$ & $\$ 52,000+$ car loan & $\$ 13,090$ & $\$ 24,811$ & $23.2 \%$ \\
\hline David & $\$ 100,000$ & $\$ 90,400$ & $\$ 52,000+$ car loan & $\$ 21,250$ & $\$ 26,984$ & $21.4 \%$ \\
\hline Andrea & $\$ 100,000$ & $\$ 84,679$ & $\$ 52,000+$ car loan & $\$ 21,250$ & $\$ 28,861$ & $20.8 \%$ \\
\hline
\end{tabular}

While the tax saved from salary sacrifice is sizeable, wages and salaries are difficult to use for many tax planning arrangements. This is because such income, typically earned from an individual's physical exertion, is difficult to allocate among various people for tax purposes. Income derived from dividends, interest, rent and other forms of investment is more flexibly able to be managed. It thus offers significant potential for large tax savings.

The most prominent form of investment in Australia is housing. Some 67 per cent of Australian households own (or their bank owns) a house in 2016 (AIHW, 2019). For many Australians, the family home is the main asset that they own in their life. Housing assets also represent a significant proportion of overall Australian wealth. Capital gains on the primary residence are fully exempt from income tax, unless the primary residence has been rented to generate a financial return for more than six years, in which case the marginal gains beyond six years of rental are subjected to a 50 per cent capital gains tax discount. The capital gains tax exemptions that apply to the primary residence are among the most broadly enjoyed tax effective arrangements in Australia.

These exemptions are exceedingly generous for those fortunate enough to experience them. Example 2 shows how a couple that jointly own a family home that experienced a $\$ 1.7$ million capital gain over 21 years, and was deployed as a financial asset for just under half of this time, can incur just a 0.9 per cent average tax rate on the overall capital gain when sold.

Capital assets such as housing provide an ancillary benefit that tax planners also value greatly. They provide the flexibility to choose the year in which to incur a tax bill. A tax liability on a capital asset is only incurred when an asset is realised, or sold, rather than when the value accrues (and the economic activity occurs). For example, a house bought in 2010 and sold in 2017 may experience an increase in economic value in each year for eight years. However, under Australian tax law, the capital gain is only incurred with the asset's sale in 2017. This means that not only are capital gains eligible for discounted tax treatment, the capital owner has complete discretion on when (or if) to realise the gain (or loss) and incur a tax liability. 


\section{Example 2. Capital gains on the primary residence}

Chris and Todd contributed equally when they bought a house in Melbourne in 1998 for $\$ 300,000$. This serves as their primary residence for the 21 years between July 1998 and July 2019. They live in the property for the first 11 years from 1998 to 2009. In July 2009, Chris and Todd accept job offers relocating them to Sydney for 10 years. They live in a rental while in Sydney. At the same time they rent out their Melbourne house to produce a (neutrally geared) financial return. Then, in July 2019, they embrace a 'sea change' lifestyle. After selling the Melbourne house for $\$ 2$ million, they buy a $\$ 1.5$ million apartment in the South Coast of NSW.

In calculating their tax bill, Chris and Todd take advantage of three capital gains tax discounts and exemptions. First, as primary residence, the capital gain for the 11 years that Chris and Todd lived in the house is tax-exempt. Second, thanks to the six-year absence exemption, the first six years of rental are exempt from tax. Chris and Todd therefore only pay tax on the final four years, which is estimated to see a capital gain of $\$ 200,000$. Third, this gain is eligible for the 50 per cent capital gains discount as the asset has been held for longer than a year. The taxable gain is just $\$ 100,000$ over the life of the property. And Chris and Todd each realise $\$ 50,000$ of this gain.

Provided the capital gain is their only personal income in 2019-20, Chris and Todd each pay $\$ 7,797$ in personal income tax. Their combined $\$ 15,594$ tax bill works out to be 0.9 per cent of the $\$ 1.7$ million lifetime capital gain, or 2.2 per cent on the $\$ 700,000$ gain since July 2009 .

Table 2.1. Capital gains tax examples

\begin{tabular}{|c|c|c|}
\hline Activity & \multicolumn{2}{|l|}{ Value } \\
\hline Purchase price & \multicolumn{2}{|l|}{$\$ 300,000$} \\
\hline Capital gain 1998-2009 & \multicolumn{2}{|c|}{$\$ 1,000,000$} \\
\hline Capital gain during six-year absence exemption period & \multicolumn{2}{|l|}{$\$ 500,000$} \\
\hline Remaining capital gain & \multicolumn{2}{|l|}{$\$ 200,000$} \\
\hline Sale price & \multicolumn{2}{|c|}{$\$ 2,000,000$} \\
\hline Total capital gain & \multicolumn{2}{|c|}{$\$ 1,700,000$} \\
\hline Capital gain that is taxable & \multicolumn{2}{|l|}{$\$ 200,000$} \\
\hline \multirow[t]{2}{*}{ Taxable gain after $50 \%$ capital gains tax discount is applied } & \multicolumn{2}{|l|}{$\$ 100,000$} \\
\hline & Chris & Todd \\
\hline Taxable income upon sale (50\% ownership split) & $\$ 50,000$ & $\$ 50,000$ \\
\hline Personal income tax & $\$ 7,797$ & $\$ 7,797$ \\
\hline
\end{tabular}

Note: Calculations for these examples are stylised. Unless otherwise specified, they are based on headline personal, corporate and/or super tax rates and thresholds only without offsets, deductions or levies such as the Medicare levy or low-income tax offset. The calculations here only concern taxes at the Commonwealth government level and not at the state, territory or local government level. 
To put this into context, if Chris or Todd individually realised $\$ 1.7$ million in wage and salary income in a single year, they would pay $\$ 738,097$ in tax an average tax rate of 43.5 per cent. If they instead realised a $\$ 1.7$ million in capital gain from jointly owned shares-\$425,000 in taxable income each after applying the 50 per cent capital gains tax discount-they would pay $\$ 164,347$ each in tax at an average rate of 38.7 per cent on the $\$ 425,000$ discounted capital gain, or 19.3 per cent on the $\$ 850,000$ capital gain.

There are more tax-advantaged alternatives too. For example, if Chris and Todd lived in the property the entire time they owned it, there would be no capital gains tax implications. If they never sold the house and instead gifted it as part of their estate, their children may escape tax. And if Chris and Todd were instead retirees aged over 65 , they could contribute up to $\$ 300,000$ post-tax income from the sale of the house into super. The tax-free 'downsizer' contribution would get around many integrity measures governing super, such as non-concessional contribution caps.

\section{The basics of advanced tax structuring: The streaming and tax deferral benefits of a bucket company and a trust}

Using a combination of entities provides taxpayers more flexibility to control when and how they receive income for tax purposes. Example 3 depicts a simple setup involving a couple, a discretionary trust and a 'bucket' company ${ }^{9}$ over a two-year horizon.

Example 3 Part 1 shows the arrangements in the first year.

\section{Example 3. Part 1. Basic tax structuring using a bucket company and a trust}

\section{Year 1: 2019-20}

Mike and Angie are both aged 32. They have worked out that they can maintain their current lifestyle on $\$ 66,000$ after tax per year. Mike operates a consulting practice that provides digital transformation analysis and advice to a range of large Australian firms. He is also trustee of a family trust, which is paid the taxable profit of \$148,000 in 2019-20 that the consulting practice generates. The trust has three beneficiaries: Mike, Angie and Family Co., a small 'bucket' company that Mike controls. Family Co. is dedicated to managing an investment portfolio and its investment strategy is to only hold cash.

9 'Bucket company' is a commonly used term to describe a passive private company set up to be a beneficiary of a trust. The 'bucket' element refers to the company sitting below the trust and having money poured into it to reduce tax. 
As trustee of the trust, Mike determines that the trust will distribute all $\$ 148,000$ of its net income to the three beneficiaries: $\$ 37,000$ to each of Mike and Angie and the remaining $\$ 74,000$ to Family Co. (If it didn't, the trust would have to pay the highest marginal tax rate of 47 per cent on retained earnings.)

Table 3.1. Example of tax structuring (Part 1)

\begin{tabular}{|l|l|l|l|}
\hline Activity & Value & \multicolumn{2}{l|}{} \\
\hline Income paid into discretionary trust & $\$ 148,000$ & Mike & Family Co. \\
\hline \multirow{2}{*}{ Distribution } & Angie & $\$ 37,000$ & $\$ 74,000$ \\
\cline { 2 - 4 } & $\$ 37,000$ & N/A & $\$ 53,650$ \\
\hline Retains & N/A & $\$ 3,752$ & $\$ 20,350$ \\
\hline Tax & $\$ 3,752$ & \multicolumn{2}{|l}{} \\
\hline Total tax & $\$ 27,854$ & \multicolumn{3}{|l}{} \\
\hline Total tax rate & $18.8 \%$ & $\$ 20,350$ \\
\hline Franking credits generated & N/A & \multicolumn{3}{|l|}{} \\
\hline
\end{tabular}

Note: Calculations for these examples are stylised. Unless otherwise specified, they are based on headline personal, corporate and/or super tax rates and thresholds only without offsets, deductions or levies such as the Medicare levy or low-income tax offset.

Under trust taxation rules, Mike, Angie and Family Co. are assessed on the proportion of trust income that they are 'presently entitled' to. In this case, present entitlement is equal to the income received. Mike and Angie each pay tax at their marginal personal income tax rates on their income. Family Co. pays tax on the $\$ 74,000$ in profit it receives at the 27.5 per cent small business tax rate. Plus, as an Australian resident corporation, it generates a $\$ 20,350$ franking credit balancewhich it considers an asset. The company holds on to the after-tax profits of $\$ 53,650$ as 'retained earnings' as well as the $\$ 20,350$ in franking credits.

In total, on $\$ 148,000$ of income in $2019-20$, the structure pays $\$ 27,854$ in tax at an average tax rate of 18.8 per cent. To put this into context, if Mike instead earned $\$ 148,000$ as a salary, he would receive a tax bill of $\$ 42,257$ ( $\$ 14,403$ more than the structure) at an average tax rate of 30.4 per cent.

There are three essential steps in the process:

- The couple operates a consulting business. Payments to the business are paid into a discretionary trust which the couple controls.

- The trust distributes enough income to the individuals such that they can meet their desired standard of living, and allocate the rest to the company.

- The company holds its profits as 'retained earnings'. It pays corporate tax on the profits and generates franking credits (an asset) on this corporate tax. 
The immediate gains from setting up a structure are lucrative: $\$ 14,403$ in first-year tax savings come from paying the small business tax rate rather than the marginal personal tax rate and streaming income across two adult family members. But it is the second year of the hypothetical arrangement that shows the full power of a trust and bucket company structure to deliver low lifetime tax rates. And it highlights the (unintended) role that Australia's refundable dividend imputation system plays as a tax planning vehicle.

When Australian businesses distribute taxed profits (at a rate of 27.5 per cent for small businesses or 30 per cent for large businesses) to their shareholders, they have the ability to pass on or 'impute' the tax by allocating imputation credits to (Australian resident) shareholders. This is called 'franking' the distribution, and imputation credits are commonly known as franking credits. Franking credits can be used be as tax offsets against marginal tax rates, providing a refundable credit against the tax the recipient would need to pay.

Franking credits are designed to prevent a situation where profits are taxed twice: once when earned by a business and a second time when the business distributes a dividend to a shareholder. A number of countries, including Canada and New Zealand, have 'one-tier' systems in place that are designed to ensure that company profits are taxed only once (Martin, 2019). That said, Australia is unique among the OECD in permitting refundable franking credits — which are designed to ensure that the taxable income of companies is taxed at the marginal tax rate of Australian resident individual shareholders when the taxable income is distributed.

Importantly, the role that franking credits play in the Australian tax system has gradually changed since its introduction in 1987. A policy designed to avoid double taxation makes it possible to engineer a zero-tax outcome. The key is to think of franking credits as a 'tax bank' in exploiting tax rate differentials. The tax bank involves a deposit and withdrawal stage. The deposit stage stems from the incentive individual taxpayers face to 'cap' their marginal tax rate at the corporate rate of 27.5 or 30 per cent, which is cheaper than a top marginal tax rate of 47 per cent (including Medicare levy). And in the process, it costs nothing for the company to generate a franking credit.

The withdrawal stage occurs during the subsequent distribution of the franked dividend to a shareholder. If the shareholder receiving the dividend is a personal income taxpayer or super fund and the income part of a tax-free threshold, they can fully 'withdraw' from government the company tax paid. When company tax is paid by one part of a tax structure and then fully refunded to another, then no net tax is received by government on the economic activity performed by the structure. This behaviour is explored further in Sainsbury and Breunig (2020a). 
It's worth acknowledging that the conceptual issue is not with refundable dividend imputation itself. Franked dividends do not need to play the tax bank role. Rather, it's the different tax treatment of companies, super and personal income. If there were no differential between marginal corporate and marginal personal tax rates, and no tax discount for super, then there would be no incentive to use franking credits in tax arbitrage. The generalised principle is that single taxation at the individual level is conceptually robust when part of a properly designed comprehensive income tax system. But this principle may not apply in a complex hybrid system.

\section{Example 3. Part 2. Basic tax structuring using a bucket company and a trust}

\section{Year 2: 2020-21}

In 2020-21, Mike has looked closely at his finances and decided that he and Angie can fund their $\$ 66,000$ annual lifestyle without him working this year. Compared to Part 1 of this example, Mike makes zero consulting income. He determines that Family Co. will provide a dividend worth all of its retained earnings $(\$ 53,650$ and franking credit balance of $\$ 20,350$ ) to the family trust. As trustee of the family trust, Mike determines that he and Angie are each entitled to half of the dividend and half of the franking credits-\$26,825 and $\$ 10,175$ respectively. Family Co. (despite being a beneficiary) receives no distribution from the trust this year.

Mike and Angie each pay tax on their $\$ 37,000$ in taxable income at their marginal personal income tax rates. They claim $\$ 20,350$ collectively in franking credits (which represents tax that has already been paid by their company to the ATO on their behalf) against \$7,504 in income tax. The couple has arrived in tax refund city. On \$74,000 of realised income, they pay $\$ 7,500$ in income tax and receive a refund on their dividends of $\$ 12,846$. Their effective average tax rate falls to 10.1 per cent in year two.

\section{Table 3.2. Example of tax restructuring (Part 2)}

\begin{tabular}{|l|l|l|l|}
\hline Activity & \multicolumn{2}{|l|}{ Value } \\
\hline $\begin{array}{l}\text { Dividend from bucket company } \\
\text { into discretionary trust }\end{array}$ & \multicolumn{2}{|l|}{$\$ 53,650+\$ 20,350$ in franking credits } \\
\hline Distribution & Angie & Mike & Family Co. \\
\cline { 2 - 4 } & $\begin{array}{l}\$ 26,825+\$ 10,175 \text { in } \\
\text { franking credits }\end{array}$ & $\begin{array}{l}\$ 26,825+\$ 10,175 \text { in } \\
\text { franking credits }\end{array}$ & \$0 \\
\hline Tax & $\begin{array}{l}\$ 3,752 \text { (on } \$ 37,000 \\
\text { taxable income) }\end{array}$ & $\begin{array}{l}\text { \$3,752 (on } \$ 37,000 \\
\text { taxable income) }\end{array}$ & \\
\hline Tax rate & $10.1 \%$ & \multicolumn{2}{|l}{} \\
\hline Net refund & $\$ 12,846$ & \\
\hline
\end{tabular}

Note: Calculations for these examples are stylised. Unless otherwise specified, they are based on headline personal, corporate and/or super tax rates and thresholds only without offsets, deductions or levies such as the Medicare levy or low-income tax offset. 
Mike and Angie have been able to fund the same after-tax lifestyle as in year one, without having to work. In nominal terms, the total tax paid is $\$ 15,008$ (four payments of $\$ 3,752$ ) at an average tax rate of 10.1 per cent. By taking advantage of income splitting, the refundable imputation system, and a trust and bucket company structure, Mike and Angie pay $\$ 27,249$ less in tax compared to a single income salary of $\$ 148,000$.

The basic logic of bucket companies and trusts extends to more complex arrangements involving more income and extra family members. Sainsbury and Breunig (2020a) show how the same framework functions for a family of four adults with a combined taxable income of $\$ 500,000$. In that case, this structure reduces an effective tax rate of 25.2 per cent in the first year to just 6 per cent over the full life of the scheme.

What's more, Sainsbury and Breunig (2020a) show how, by staying entirely within the tax-free thresholds available for personal taxpayers and in super, a wealthy retired couple can finance a generous $\$ 140,000$ post-tax lifestyle- of which $\$ 42,000$ is tax refund - at a negative effective tax rate in the second year of the scheme. Over the course of approximately 10 years of this structure, the couple would be refunded the entire tax bill paid by their company in one year of the arrangement. They have found a way to convert their company tax into a temporary, interest-free loan to government.

In Sainsbury and Breunig (2020a), we document other schemes that can be used, including the combination of a small business and a self-managed superannuation fund and the combination of a trust with a bucket company and distributing income to multiple family members.

\section{Do people respond to tax planning incentives?}

Taxpayers are increasingly engaging with the kinds of tax vehicles illustrated in the examples. The most obvious trend since the turn of the century has been the growth in the number of trusts and self-managed super funds (Figure 2). Since 19992000 , the number of trusts has close to doubled, from approximately 450,000 to 875,000 , and the number of self-managed super funds has more than tripled, from approximately 150,000 to 500,000 . This compares with a one-third increase in individual tax filers (from 10.1 million to 13.9 million) and two-thirds increase in companies (from 600,000 to 970,000). Part of the growth in trusts and selfmanaged super funds is coming from the declining interest in partnerships, which are generally more restrictive than trusts. 


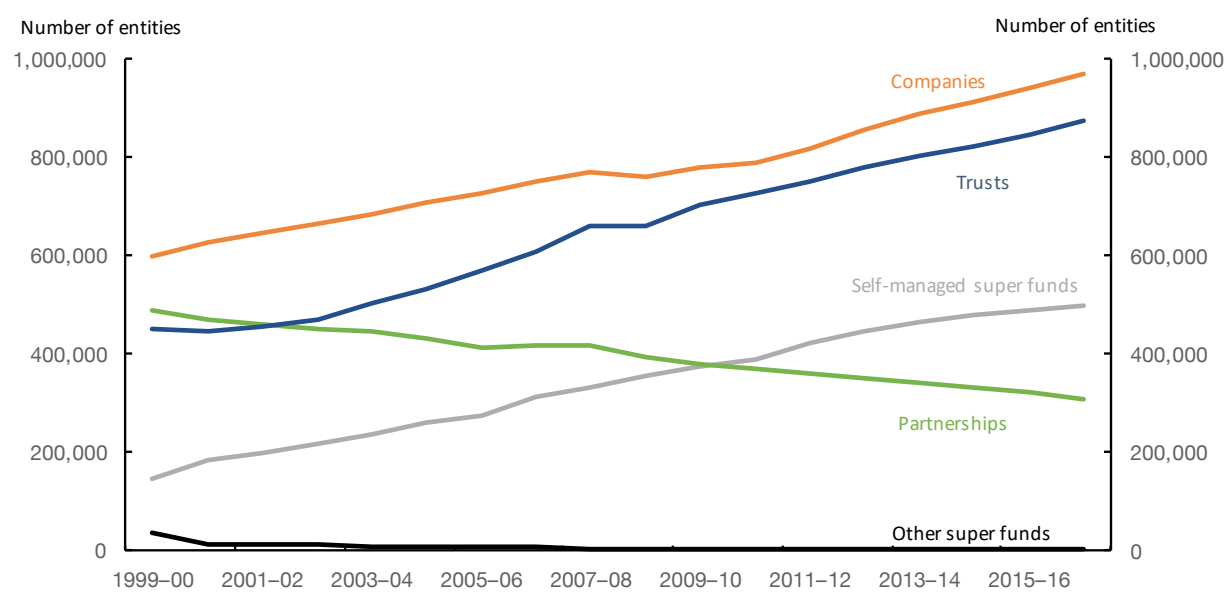

Figure 2. Number of companies, trusts, super funds and partnerships in Australia Source: ATO (2019a), Snapshot Table 6.

In addition, there is a relatively extensive academic literature (which is also growing as administrative taxation data becomes more accessible) pointing to taxpayers' propensity to respond to tax incentives. Academic empirical studies-including international studies such as Feldstein (1999), Saez (2010) and Kleven (2016) as well as Australian-focused studies such as Johnson and Breunig (2016)—observe that the bigger the difference in marginal rates, the greater the tendency for taxpayers to structure their affairs. In addition, there is a higher propensity to respond to incentives by those who derive their income in more flexible forms.

Some estimates have been produced about the tax revenue at stake as a result of specific strategies. For example, in 2019 a team of RMIT researchers identified a number of sophisticated strategies using discretionary trusts, which they estimated to shelter as much as $\$ 1.2$ billion in tax annually (de Silva et al., 2019).

However, as yet, comprehensive Australia-wide evidence on the extent of tax planning-evidence that combines the number of entities with the total value of tax at stake-is something of a blind spot for research. This is partly due to the challenges in assessing how much tax planning is occurring. The income that tax authorities observe (and audit) is what has occurred after a significant amount of legal tax planning has taken place. The strong assumptions required to arrive at a counterfactual amount of taxable income someone 'should otherwise be earning' before they tax plan suggests that such exercises would quickly become assumption and values-driven.

Even if a counterfactual could be robustly determined, measurement would be a challenge. Those embarking on tax planning activities tend to prefer to keep their arrangements private. One of the features of trusts, in particular, has been their anonymity and secrecy, as well as their propensity to be combined in very 
complex ways. As a result, getting a complete picture on the amount of income that is directed through trusts, and especially complex structures, remains notoriously difficult. Building on this evidence base is one of the more compelling and pressing areas that warrants further analysis.

\section{Tax planning and the principles of good tax design}

Individuals benefiting from particular tax planning outcomes are likely to view these as a great development that should be retained. However, a tax system that includes widespread incentives to tax plan is problematic in a number of important respects.

\section{Less fair}

First, a strong argument can be made that some Australians responding to the incentives while others cannot reduces the fairness of the tax system.

As a range of authors (such as Konow, 2003, and Davis et al., 2019) have argued, notions of fairness are subjective, nebulous and contested. They are based on morals and ethics, with arguments drawn from a number of competing theories and philosophies of distributive justice. They are heavily context-dependent; for example, they are influenced by where 'you' are (the tax rate that applies to 'your' income) relative to someone else. And there is no single viewpoint as to what is fair. Fairness requires value judgements.

The fundamental ideas that vertical and horizontal equity embody-that those in similar positions are treated similarly, and those more favourably placed are required to pay more-are crucial to public acceptance of the Australian self-assessment system, which relies on people voluntarily reporting and complying with their tax obligations.

Tax planning works to undermine horizontal equity. Australians earning similar amounts of income from similar activities do not pay similar amounts of tax, with the size of discrepancy based on whether (or how much) they structure their affairs. The discrepancy becomes more pronounced for particular types of income.

In undermining horizontal equity, tax planning also undermines vertical equity. If people in the same position are not treated the same, it is impossible to trust that those on higher incomes are actually paying more. To put it another way, a system that is notionally progressive in shape may not be progressive in practice. 
The discrepancy between people's capacity to pay and their tax paid becomes more acute when considering that those on higher incomes are likely to have more income to devote to planning, and a stronger motivation to avoid higher tax rates, including the top marginal personal tax rate. The consideration becomes even more stark when considering the cumulative benefits that accrue from planning over many years, and that may ultimately benefit future generations within a single family.

\section{Less efficient}

Second, the same tax system design feature that acts as an incentive for tax planners - tax rate differentials over time-also works to distort the allocation of Australian national resources. Specifically, the Australian hybrid income tax design imposes efficiency costs on the Australian economy in three ways: through a higher rate, narrower base personal income tax schedule; by fostering a tax advice industry whose presence diverts societal resources away from more productive enterprise; and by biasing tax investors towards low-tax investments.

The Australian tax system is a variant of a high rate, narrow base structure that is in direct opposition to the key learnings from the optimal tax literature (Mankiw et al., 2009). Non-planners are the high rate taxpayers in the system. They generally face the incentives embedded in the statutory personal income tax rate tiers. Tax planners are the low rate taxpayers in the system. For the same economic activity, they can assume a different legal form to achieve a lower tax rate. And because the tax planners are able to realise a lower average tax rate for themselves, tax authorities must impose higher statutory marginal tax rates on the population as a whole for a given revenue-raising objective. It is also worth bearing in mind that at the economy-wide level, tax planners are engaging an industry whose presence diverts societal resources away from more productive enterprise.

If we were to restrict consideration of the efficiency of tax planning decisions only to the subset of people's choices that concern the investment of their savings, ${ }^{10}$ then a tax system design that has neutral impact on taxpayer investment decisions and associated financing decisions may have little impact on the pattern of investment (see, for example, Samuelson, 1964, and King, 1977). If the pattern of investment is minimally affected by income taxation, then for the tax planning cohort the productivity loss, long-term growth effect and adverse efficiency effects might be overstated.

\footnotetext{
10 'Savings' here is defined as income that is not required to satisfy current consumption needs. In general, tax planner decisions will be more complex than just how best to invest savings. They can be expected to seek to lower the effective tax rate across all income sources, not just savings, and to seek out opportunities for tax arbitrage without changing economic engagement.
} 
But this highlights a related feature of Australia's tax structure: the non-neutral tax treatment of different investment options. Some asset classes (such as interest on bank savings) attract marginal personal tax rates, while others (owner-occupied housing and superannuation) have tax-free thresholds. Australians have in aggregate responded to the tax-free status of key investment choices (Sainsbury \& Breunig, 2020b). In 2017-18, more than 70 per cent of Australians' net worth was invested into housing and superannuation (Australian Bureau of Statistics, 2019). Such an asset portfolio suggests that Australia's tax settings are a prominent part of a broader public policy landscape that is biasing people's - and firms'-lifetime decisions towards particular domestic asset classes. In the process, the tax system is detracting from the efficient allocation of Australian economic resources.

\section{More complex}

Third, tax planning can be considered both a feature of and a driver of a complex tax system. As the 2015 Tax White Paper acknowledged, Australia's tax system is complex:

the complexity of the Australian tax system [which largely reflects the historical foundations of the tax system and the way the changes have been implemented in the past] reduces integrity and transparency, and imposes unnecessary compliance costs on taxpayers, as well as other costs on the Australian economy. (Australian Treasury, 2015, 'At a glance' Complexity section)

Tax structures can be technical and require specialist expertise to understand and enact. There is a financial cost both to set up and to maintain such arrangements. Further, the more complex a structure and the more income at stake, the greater risk to taxpayers if the structure were to run afoul of tax authorities. The resulting 'compliance' activities impose a financial and emotional toll, and often divert the taxpayer's focus from other aspects of their life. As a result, taxpayers typically turn to the tax advice industry, and are at least partly motivated to outsource as much of the 'running afoul of tax authority' risk as possible to a professional tax planner.

\section{Less sustainable}

Tax planning also raises questions around the sustainability of the Australian tax system. Figure 3 is a stylised representation of the kind of stylised 'cost-benefit' choices that tax administrators and policymakers face. The hypothetical tax system might initially move along a trajectory where government receipts match that which would be expected if all citizens were all paying at their marginal personal tax rates. But over time, as some of the population lower their average tax rates, a wedge opens up between the (theoretically) full collection level and actual collections. 


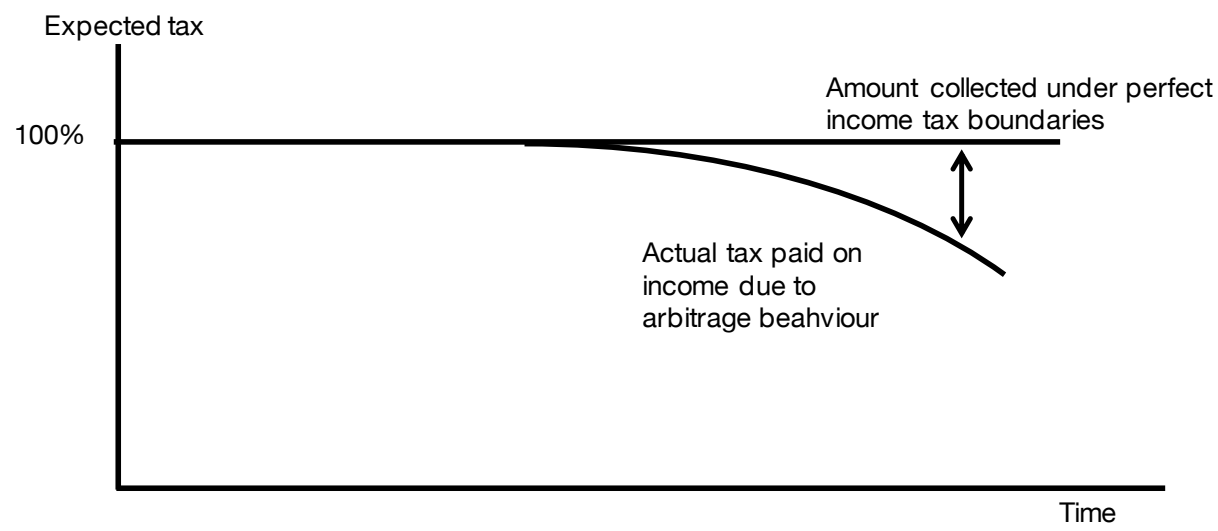

Figure 3. The cumulative cost of tax planning over time

Source: Authors' representation.

The growth in this wedge will not be a 'linear' progression. The wedge can, in general, be anticipated to cumulatively increase over time, as new tax planning opportunities are discovered and tax advisers overcome the fixed costs from developing necessary expertise and road-testing the advice. However, once a robust opportunity is developed, the marginal costs of marketing the advice and otherwise increasing the number who can access it are likely to be low.

Policy settings also often take time to 'catch up'. The tax planning opportunity is only likely to arrive on the policymaking radar once 'revenue leakage' reaches a sufficient level, at which point there will be pressure on governments to fix the hole through a policy change. If the policy response is such that the opportunity is closed off entirely, then the revenue collections might return to the original collection level.

Equally importantly, there is a risk that taxpayers that are not benefiting from tax planning will lose faith in the system and find ways to avoid paying taxes themselves. This might, at some point, include increased action in the informal economy. The risk grows as the number of opportunities for tax minimisation across the economy proliferates.

It's worth acknowledging that while this is (currently) a vulnerability, Australia continues to reliably collect large sums of money from direct taxation. For example, the 2019-20 Mid-Year Economic and Fiscal Outlook estimated that \$231 billion will be collected in 2018-19 from individuals and other withholding taxes (Frydenberg \& Cormann, 2019b). But, as Davis et al. (2019) revealed, personal income tax has in recent decades become increasingly concentrated among a narrower band of top earners. In 2016-17, Australia collected 45 per cent of personal income tax revenues annually from approximately 1 million top-earning taxpayers earning at least $\$ 125,000$ annually and paying an average tax rate of 35 per cent on their taxable income. The composition of the top decile of taxpayers changes over time, 
but the membership shares a common incentive to lower their marginal tax rates. So, there are reasons to be alert to the risk that the revenue base could erode. In particular, should the trajectory of Australian revenue collections proceed in the stylised manner depicted in Figure 3, it is reasonable to anticipate some future point at which revenue collections erode.

\section{Where to go from here?}

Policymakers could take one of four generic courses of action in response to tax planning:

- Do nothing. Persist with the current hybrid income tax approach. Either implicitly or explicitly drop horizontal equity as a fundamental principle guiding the design of the tax system. And accept that public acceptance of the tax system will continue to be questioned.

- Give everyone access to a 'no income tax' outcome. Instead of taxing income, move the taxation base entirely over to an expenditure tax base, perhaps combined with an estate tax that is set at consumption tax rates and designed to ensure the integrity of the consumption tax regime. This would be a significant shift in composition of revenue collections.

- Close the incentives to arbitrage. The general principle would be to directly address the incentives to arbitrage by closing (or significantly reducing) the gap between marginal personal tax rates and the corporate, super and capital gains rates on an enduring basis.

- Close the opportunities to arbitrage. The general principle would be regulating additional constraints around the use of common vehicles that 'work across' different income types, and considering the prohibition of tax vehicles entirely if more narrow solutions are not pragmatic.

These design options go deep into the basic design of tax. Accordingly, they have, in the (relatively) recent past, been within the remit of major tax reviews in the spirit of the Review of Australia's future tax system (Australian Treasury, 2009) and Tax by design, the final report from the Mirrlees Review in the United Kingdom (Mirrlees et al., 2011). This article does not aspire to be a 'solutions' paper in the spirit of such weighty reports. We won't advocate for a particular form of the Australian tax mix here. Instead, we advocate for an informed public policy conversation around which approach to taxation is most appropriate.

We will point out an important further consideration: that while incremental, piecemeal changes to specific sources of tax can contribute positively to Australia's tax system, adequately addressing tax planning requires 'big bang' comprehensive reform that is implemented simultaneously across multiple sources of tax. Consider 
the impact of one of the most consequential tax changes (in terms of revenue cost) in the past decade - the seven-year tax personal income tax plan-on marginal tax rates and arbitrage incentives.

On the face of it, reducing marginal personal income tax rates from as high as 47 per cent to as high as 30 per cent (excluding the Medicare levy) for those earning less than $\$ 200,000$ in a year (estimated in the 2019-20 Budget to cover up to 94 per cent of the taxpaying population (Frydenberg \& Cormann, 2019a)) will reduce the discrepancy between marginal personal and corporate tax rates and thereby reduce the initial incentive for salaried employees to set up and operate as a company. However, tax planners will still have incentives to use franking credits to achieve tax refunds. Moreover, for those realising between $\$ 50,000$ and $\$ 200,000$, there will be a more prominent incentive to earn income through capital gains rather than through corporate profit making, wage and salary earning.

\section{Conclusion}

This article has highlighted a range of tax planning opportunities in Australia.

Australia's tax system contains opportunities for some taxpayers to adopt legal arrangements that enable them to pay less tax than comparable taxpayers, for the same economic activity. Some Australians are able to access these arrangements, with different opportunities appealing to different taxpayers and being of interest at different stages of people's lives.

We have also revealed that the various parts of Australia's income tax system are part of an interconnected whole. Appreciating tax planning requires a whole-oftax-system perspective, with limits inherent in examining just an individual base, an individual element of the system or an individual year in isolation.

It's not a surprise that taxpayers respond to the incentives they face. However, a tax system designed to encourage tax planning is an affront to the commonly held core principles of good tax design of fairness, efficiency and simplicity. In particular, widespread tax planning points to failure of Australian tax policy to give appropriate weight to horizontal equity considerations.

Conceptually, a taxpayer's after-tax outcome should be much the same as that of any other broadly equivalent taxpayer, and should be based on the economic activity they undertake rather than the legal fiction they use. To put it another way, taxpayers earning the same income should pay the same amount of tax, irrespective of how they have chosen to structure their affairs. 
If Australia remains committed to the principle of horizontal equity, then policymakers and political leaders will need to re-examine the rationale behind every aspect of our personal income tax system, and assess whether they remain appropriate in the modern Australian economy. Such an evaluation will need to take place in the wider context of the tax and transfer system.

\section{References}

Australian Bureau of Statistics. (2019). Survey of income and housing 2017-18. Catalogue 6553.0.

Australian Institute of Health and Welfare. (2019). Australia's welfare snapshots 2019: Home ownership and housing tenure. Australian Government. www.aihw.gov.au/reports/ australias-welfare/home-ownership-and-housing-tenure.

Australian Taxation Office. (2019a). Taxation statistics 2016-17 [Data set]. Data.gov.au. data.gov.au/data/dataset/taxation-statistics-2016-17.

Australian Taxation Office. (2019b). Taxation statistics 2016-17: Individuals 100 people statistics. Australian Government. www.ato.gov.au/About-ATO/Research-and-statistics/In-detail/ Taxation-statistics/Taxation-statistics---previous-editions/Taxation-statistics-2016-17/? page $=8$.

Australian Taxation Office. (2020). Tax planning. Australian Government. www.ato.gov.au/ General/Tax-planning/.

Australian Treasury. (2009). Australia's future tax system review (Final report). Australian Government. treasury.gov.au/review/the-australias-future-tax-system-review.

Australian Treasury. (2015). Tax white paper (Discussion paper). Australian Government. treasury.gov.au/review/tax-white-paper.

Commonwealth of Australia. (2020). Tax benchmarks and variations statement 2019. Australian Government. treasury.gov.au/sites/default/files/2020-01/complete_tbvs_web.pdf.

Davis, G., Akroyd, P., Pearl, D. \& Sainsbury, T. (2019). Recent personal income tax progressivity trends in Australia (Treasury Working Paper 2019-05). Commonwealth of Australia. treasury.gov.au/sites/default/files/2019-09/p2019-t396438.pdf.

De Silva, A., Glover, J., Narayanan, V., Nguyen, T. \& Westberg, K. (2019). Current issues with trusts and the tax system. Australian Taxation Office. www.ato.gov.au/About-ATO/ Research-and-statistics/In-detail/General-research/Current-issues-with-trusts-and-thetax-system/.

Feldstein, M. (1999). Tax avoidance and the deadweight loss of the income tax. Review of Economics and Statistics, 81(4), 674-680. doi.org/10.1162/003465399558391. 
Frydenberg, J. \& Cormann, M. (2019a, April). Budget strategy and outlook 2019-20 (Budget Paper No. 1, 2019-20). Commonwealth of Australia. budget.gov.au/2019-20/content/ bp1/index.htm.

Frydenberg, J. \& Cormann, M. (2019b, December). Mid-year economic and fiscal outlook 2019-20. Commonwealth of Australia. budget.gov.au/2019-20/content/myefo/index.htm.

Haig, R. (1921). The concept of income-Economic and legal aspects. In R.M. Haig (Ed.), The Federal Income Tax (pp. 1-28). Columbia University Press. archive.org/details/ cu31924020062935/page/n9.

Johnson, S. \& Breunig, R. (2016, 10 November). Taxpayer responsiveness to marginal tax rates: Bunching evidence from the Australian personal income tax system [Speech]. The 29th $\mathrm{PhD}$ Conference in Economics and Business, University of Western Australia.

King, M. (1977). Public policy and the corporation. Chapman and Hall, London.

Kleven, H. (2016). Bunching. Annual Review of Economics, 8, 435-464. www.annualreviews. org/doi/abs/10.1146/annurev-economics-080315-015234.

Konow, J. (2003). Which is the fairest one of all? A positive analysis of justice theories. Journal of Economic Literature, 41(4), 1188-1239. doi.org/10.1257/002205103771800013.

Mankiw, G., Wienzierl, M. \& Yagan, D. (2009). Optimal taxation in theory and practice. Journal of Economic Perspectives, 23(4), 147-174. doi.org/10.1257/jep.23.4.147.

Martin, P. (2019, 11 February). Words that matter. What's a franking credit? What's dividend imputation? And what's 'retiree tax'? The Conversation. theconversation.com/wordsthat-matter-whats-a-franking-credit-whats-dividend-imputation-and-whats-retireetax-111423.

Mirrlees, J., Adam, S., Besley, T., Blundell, R., Bond, S., Chote, R., Gammie, M., Johnson, P., Myles, G. \& Poterba, J. (2011). Tax by design. Oxford University Press. www.ifs.org. uk/publications/5353.

Organisation for Economic Cooperation and Development. (2019a, December). OECD Revenue Statistics 2019. Organisation for Economic Cooperation and Development. www.oecd.org/tax/tax-policy/revenue-statistics-2522770x.htms.

Organisation for Economic Cooperation and Development. (2019b, December). OECD Revenue Statistics 2020-Australia. Organisation for Economic Cooperation and Development. www.oecd.org/tax/revenue-statistics-australia.pdf.

Saez, E. (2010). Do taxpayers bunch at kink points? American Economic Journal: Economic Policy, 2(3), 180-212. doi.org/10.1257/pol.2.3.180.

Sainsbury, T. \& Breunig, R. (2020a). The Australian tax planning playbook: Volume 1 (Working Paper 1). Tax and Transfer Policy Institute. taxpolicy.crawford.anu.edu.au/publication/ ttpi-working-papers/16280/australian-tax-planning-playbook-volume-1. doi.org/10.2139/ ssrn.3553095. 
Sainsbury, T. \& Breunig, R. (2020b). Covid-19 has exposed the weaknesses in the Australian tax system: Tax reform will be required for recovery. Australian Journal of Labour Economics, 23(2), 211-229.

Samuelson, P. (1964). Tax deductibility of economic depreciation to insure invariant valuations. Journal of Political Economy, 72, 604-606. doi.org/10.1086/258967.

Schanz, G. (1896). Der Einkommensbegriff und die Einkommensteuergesetze [The concept of income and the income tax laws]. Finanzarchiv, 13, 1-87.

Simons, H. (1938). Personal income taxation: the definition of income as a problem of fiscal policy. University of Chicago Press. 
This text is taken from Agenda, Volume 27 - Number 1, 2020, edited by William Coleman, published 2020 by ANU Press, The Australian National University, Canberra, Australia.

doi.org/10.22459/AG.27.01.2020.03 